臨床 単クローン性免疫グロブリン血症を伴つた

\title{
自己免疫性好中球減少症
}

\author{
九州大学医学部第三内科 \\ 小鶴 三男॰ 中島 泰代 藏田 孝雄 \\ 金子 周司 井林 博

\section{AUTOIMMUNE NEUTROPENIA ASSOCIATED WITH MONOCLONAL GAMMOPATHY}

Mitsuo Kozuru, MD, Yasuyo Nakashima, MD, Takao Kurata, MD, Shushi K ANeko, MD and Hiroshi IBayashi, MD

The Third Department of Internal Medicine, Faculty of Medicine, Kyushu University, Fukuoka

\begin{abstract}
概要 好中球減少症（35才，男性）に批いて，副督皮質ステロイド使用後に増加してきた自己成熟好 中球に対する凝集素をLalezariの方法によつて梌索し，本症が自己免疫性好中球抗体に起因すること を証明した，本例の成熟好中球は末梢血および骨䯣中に著減を示したが，骨髄芽球，好中球系の前骨

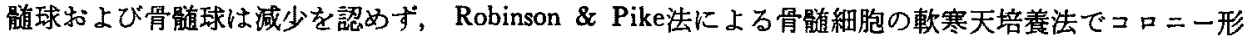

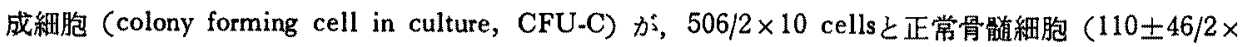

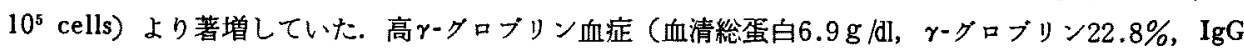
$1800 \mathrm{mg} / \mathrm{dl}$, IgA 333mg/dl, IgM 516mg/dl, TTT 13.5, ZTT 21.2) を合併し, セルローズフセテート 膜電気泳動で尖鋭なピークが認められ，免度電気泳動でIgM（ 好中球自己抗体が単クローン性IgM ( $(\kappa)$ にあるのか否かを追究する目的で, 患者血清を薄㬝等笪点 分画法によつてIgGとIgMに分離した後，Lalezariの方法によつて白血球凝集素を検索したところ， 好中球抗体はIgGにあることが判明した．副腎皮質ステロイドに極めて良く反応し，プレドニデロン $40 \mathrm{mg} /$ 日の投与で 1 週間後には好中球数 $396 / \mathrm{mm}^{3} か 52840 / \mathrm{mm}^{3}$ と著增した. 血清の白血球凝集素は2048 倍以上から, ステロイド使用後急速に低下して陰性化した. 以上, 本邦第 1 例の自己免疫性好中球減 少症を報告すると共に，好中球抗体の検索法，好中球特異抗原，同種新生児好中球减少症，Felty症 候群，SLEなどの鑑別骖断などについて考察した。
\end{abstract}

\section{粕言}

赤血球自己抗体によつて自己免疫性溶血性貧血 が萑起され，また特発性血小板減少性紫斑病にお けることく血小板自己抗体によつて血小板減少症 が招来されることは良く知られた事実である。し かし，好中球減少症における自己抗体の存在に関 しては1952年頃から追究されてきたが，その検出

[昭和53年 9 月 2 日 第162回九州地方会推薦]
法に疑義がもたれていた. Lalezari らは, leucoagglutinin testの改良法を開発し1)，1975年，2才 少女の自己免疫性好中球減少症の症例 ${ }^{2)}$ 報告し て以来, 約 10 例の自己免疫性好中球減少症 が報 告されている．著者らはLalezariらの方法によつ て，35才，男性の好中球減少症が自己抗体による ことを実証したので臨床経過を含めて報告する。 な拉, 本症例は本邦第 1 番目の自己免疫性好中球 減少症の報告例であり, 血清中に単クローン性免 
疫グロブリン血症を伴つている点では現在文献的 に唯一の症例である。

\section{症列}

患者： RM, 35才, 男性 (教師).

主訴：発熱.

家族歴：特記すべき事なし.

生活歴：飲酒 3 合/週, 㚙煙 20本/日, 常用 薬 (一).

既往歴：昭和52年10月, 椎間板へルニア.フ レルギー (一), 輸血 $(-)$.

現病歴：元来, 上気道炎に罹患しやすかつた が，52年11月11日頃より高熱と咽頭痛があり，近 医で下熱剤の投与を受ける（アスピリン等）す軽 快せず，1 週間後の検査で初めて好中球减少（白 血球 2900 好中球 $3 \%$ ) を指摘された，ステロイド 薬投与にて症状軽快するる減量すると好中球減少 が生じるため, 精査の目的で53年 2 月27日九大第 三内科に入院した。

入院時現症：身長 $163 \mathrm{~cm}$, 体重 $60 \mathrm{~kg}$. 意識清 明, 脈拍72/分整, 貧血, 黄㾝なし, 咽頭発赤な し, 扁桃肥大なし, 䫓部リンパ節腫脹なし, 甲状 腺腫なし, 胸部異常なし, 腹部肝脾腎触知せず， 下肢浮腫なし, 神経学的所見異常なし, 関節異常 なし，血圧124/74ming.

一般検查成綂：検便，検尿で異常なく，血 沈は 1 時間 $8 \mathrm{~mm}, 2$ 時間 $22 \mathrm{~mm}$. 検血ではHb 14.2 $\mathrm{g} / \mathrm{dl}, \mathrm{RBC} 452 \times 10^{4}, \mathrm{WBC} 2200$ で, 好中球(桿 状核 $5 \%$, 分葉核 $9 \%$, 好酸球 $0 \%$, 好塩基球 0 $\%$, 単球 $7 \%$, リンパ球 $75 \%$ ), 血小板 $19.6 \times 10^{4}$ であり，好中球減少症が明らかに認められた。 血清生化学的検查では, ニレステロール $180 \mathrm{mg} / \mathrm{dl}$, glucose $100 \mathrm{mg} / \mathrm{dl}$, BUN $7.5 \mathrm{mg} / \mathrm{dl}$, 尿酸 $6.7 \mathrm{mg} / \mathrm{dl}$ クレアチニン $0.8 \mathrm{mg} / \mathrm{dl}$, 総ビリルビン $0.4 \mathrm{mg} / \mathrm{dl}$, アルカリフォスファターゼ $60 \mathrm{mU} / \mathrm{ml}, \mathrm{LDH} 160 \mathrm{~m}$ $\mathrm{U} / \mathrm{ml}$, GPT $30 \mathrm{mU} / \mathrm{ml}$, GOT $35 \mathrm{mU} / \mathrm{ml}$, トリグ

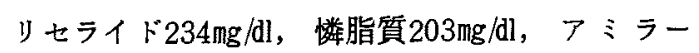
ぜ118Unit，血清鉄 $100 \mu \mathrm{g} / \mathrm{dl}, \mathrm{Ca} 9.0 \mathrm{mg} / \mathrm{dl}, \mathrm{Na}$ $138 \mathrm{mEq} / l, \mathrm{~K} 4.3 \mathrm{mEq} / l, \mathrm{Cl} 105 \mathrm{mEq} / l$. 血清総 蛋白 $6.9 \mathrm{~g} / \mathrm{dl}, \mathrm{ALb} 56.8 \%, \alpha_{1}-\mathrm{gl} 3.8 \%, \alpha_{2}-\mathrm{gl}$
$5.8 \%, \beta-\mathrm{gl} 10.5 \%, \gamma-\mathrm{gl} 22.8 \%$ で, 軽度の $\gamma$ グロブリンの增加があり，七ルローズアセテート 膜電気泳動で $\gamma$-グロブリンの陰極側に炎鋭なピー クが認められた。TTT 13.5, ZTT 21.2と著増を みた。

骨髄像 およひ顆粒球単球系造血幹細胞 (CFUC) ;

九大第三内科入院後副腎皮質ステロイドを中止 した時点（昭和53年 3 月 2 日）の骨䯣有核細胞 $6.3 \times 10^{4}$ 中，顆粒球は $45.4 \%$ 占め， $\mathrm{Mbl} 4.8 \%$ 好中球系のPromy. $13.6 \%, \mathrm{My} .10 .0 \%$, Meta $5.2 \%$, Band 5.0\%, Seg. 5.4\% と好中球の成熟 型が少なく，一見いわゆる“maturation arrest”の 像であつた（表1).

Robinson \& Pike)による骨䚙細胞の 軟寒天培 盖法では 5 月10日のステロイド使用前にはCFU-

表 1.ステロイド使用前後の骨䯣像

骨像 :

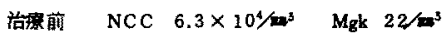

\begin{tabular}{|c|c|c|c|c|c|}
\hline Mbl & 4.8 & Mono & 6.4 & \multirow[b]{2}{*}{ Macr $\mathrm{F}$} & 0 \\
\hline Pro & 13.6 & L gmpho & 19.6 & & 0.8 \\
\hline$=$ Myel & 10.0 & Plasma & 2.0 & $\underline{0}$ & 0 \\
\hline Meta & 5.2 & Reticuhum & 0.4 & \multirow{3}{*}{ Noxm } & 1.4 \\
\hline $\pm S_{t}$ & 5.0 & Hist-B & 0 & & 22.0 \\
\hline $\mathrm{Sg}$ & 5.4 & Mgk & 0.2 & & 1.2 \\
\hline Pro & 0 & Other & 0 & Mitosi & 0.6 \\
\hline Myel & 0.2 & & & & \\
\hline Meta & 0 & & & & \\
\hline$S_{t}$ & 0.4 & & & & \\
\hline$\sqrt[28]{S_{g}}$ & 0.4 & & & & \\
\hline Baso & 0 & & & & \\
\hline Mitosis & 0.4 & & & & \\
\hline Total & 45.4 & Total & 28.6 & Total & 26.0 \\
\hline
\end{tabular}

治痖挠 NCC $10.8 \times 10^{4} / \mathrm{m}^{3} \mathrm{Mgk} 0 / \mathrm{ne}^{3}$

\begin{tabular}{|c|c|c|c|c|c|c|}
\hline \multicolumn{2}{|c|}{$\mathrm{Mbl}$} & 0.6 & Mono & 4.8 & \multirow{3}{*}{ Macr } & 0 \\
\hline \multirow{2}{*}{$\frac{2}{2}$} & Pro & 3.4 & Lympho & 20.0 & & 0.2 \\
\hline & Myel & 8.6 & Plasma & 1.0 & & 0 \\
\hline 15 & Meta & 6.6 & Reticulum & 0.6 & \multirow{3}{*}{ Nor m } & 0.6 \\
\hline \multirow{2}{*}{ 表 } & St & 15.2 & Hist-B & 0 & & 12.0 \\
\hline & $s_{g}$ & 22.8 & Mgk & +0 & & 1.8 \\
\hline \multirow{5}{*}{ 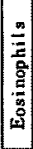 } & Pro & 0 & Other & 0 & Mitosis & 0.4 \\
\hline & Myel & 0 & & & & \\
\hline & Meta & 0.4 & & & & \\
\hline & St & 0.2 & & & & \\
\hline & $\mathbf{S}_{\mathrm{g}}$ & 0.8 & & & & \\
\hline \multicolumn{2}{|c|}{ Baso } & 0 & & & & \\
\hline \multicolumn{2}{|c|}{ Mitos is } & 0 & & & & \\
\hline \multicolumn{2}{|c|}{ Total } & 58.6 & Total & 26.4 & Total & 15.0 \\
\hline
\end{tabular}


表 2. 骨髅細胞中のコロニー形成細胞 (CFU-C)

\begin{tabular}{|c|c|c|c|}
\hline $\begin{array}{l}\text { CFU-c Incidence } \\
\text { Small-colony } \\
\text { Medium-colony } \\
\text { Large-colony }\end{array}$ & $\begin{array}{l}\text { Mar. } 10 \\
506 / 2 \times 10^{5} \\
33 \% \\
31 \% \\
36 \%\end{array}$ & $\begin{array}{l}\text { Jul. } 20 \\
6812 \times 10^{5} \\
47 \% \\
2 \% \% \\
24 \%\end{array}$ & 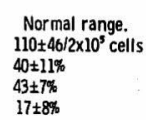 \\
\hline $\begin{array}{l}\text { Compact-colony } \\
\text { Intermediate-colony } \\
\text { Loose-colony }\end{array}$ & $\begin{array}{r}52 \% \\
40 \% \% \\
8 \%\end{array}$ & $\begin{array}{l}33 \% \\
42 \% \\
19 \%\end{array}$ & $\begin{array}{l}29 \pm 11 \% \\
49 \pm 9 \% \\
22 \pm 6 \%\end{array}$ \\
\hline
\end{tabular}

C (colony forming cell in culture) $10^{5}$ cells と正常骨䯣より増加し, 特にcompact colonyの増加を認め, ステロイド使用後に骨髄像 および，CFU-Cはともに正常化した（表 2 ）.

血清学的検查 ; CRP (-), ASLO 125, RA $(十)$, LE-テスト (一), クームステスト（直接 法) $(-)$, 抗核抗体 $(+), 8 \mathrm{x}$, クリオグロブリン (一), HB抗原 (一), ワッセルマン反応 (一), 兔 疫グロブリンでは，IgG 1800mg/dl，IgA 333mg/dl， IgM $516 \mathrm{mg} / \mathrm{dl}$ で, 特にIgMの著増をみた。血清蛋 白の免疫電気泳動では， IgM ( $(\kappa)$ の Mbow が明 らかに認められた（図 1).

Immunoelectrophoresis

P: Patient, Autoimmune Neutropenia (Matsunaga) N : Normal Human Serum

Anti-Gamma Chain

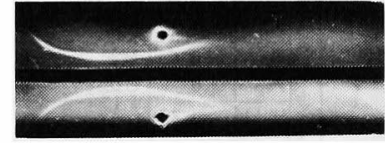

Anti-Alpha Chain

$P$

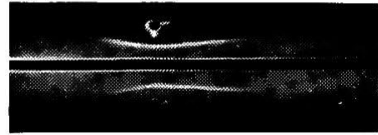

Anti-Mu Chain

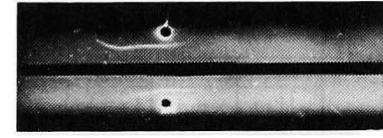

Anti-Kappa Chain

Anti-Lambda Chain

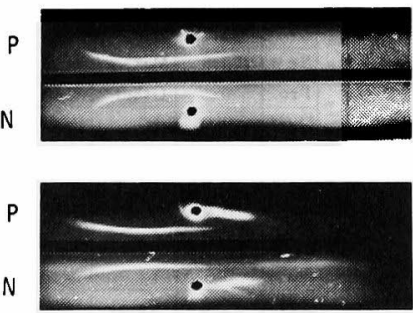

図 1. 血清の免疫電気泳動
白血球凝集素に関する検索； ステロイド使用 前の血清をー $20^{\circ} \mathrm{C} に$ 保存して拉さ，ステロイド使 用後に增加してきた自己の成熟好中球に対する白 血球凝集素leucoagglutininの 有無をLalezariのg 法”によつて検索し，陽性の所見を得た。

末梢血 $20 \mathrm{ml}$ をパリン採血し, 注射器のまま $37^{\circ} \mathrm{C}, 1 \sim 2$ 時間倒立 し, 白血球層を採取し， Ficoll-Diatrizoate (Ficoll-Paque ; Pharmecia) 重層し，1800rpm，30分間遠沈し最下層の 沈渣 (顆粒球十赤血球)を分離した。 さらにACD液にて 2 回洗浄 (1400rpm, 10分および1200rpm, 10分) 乙, トリ $ᄌ \mathrm{NH}_{4} \mathrm{Cl}$ (A) $\mathrm{NH}_{4} \mathrm{Cl} 0.8 \mathrm{~g} / 1000 \mathrm{ml} \mathrm{H} \mathrm{H}_{2} \mathrm{O}$, (B)トリス緩衝液一トリス $20.6 \mathrm{~g} / 100 \mathrm{mlH}_{2} \mathrm{O}$, 濃 塩酸でpH 7.2〜7.4に調整一A：Bを 9 容：1容 に混合）で， $37^{\circ} \mathrm{C} ， 5$ 分間処置して赤血球を溶 血させ, $\mathrm{ACD}$ 液にて 2 回洗浄後, $0.01 \mathrm{M}, \mathrm{pH} 7.2$ phosphate buffered saline $て 1$ 回洗浄後， $5 \%$ ヒトアルブミンに浮遊させ細胞数を $4000 / \mathrm{mm}^{3}$ に調 整し，10\% EDTAを $9 ： 1$ の割合に加えた。

直径7.5mmの小試験管 (non-siliconized) に検体 血清 $0.1 \mathrm{ml}$ 生理的食塩水により倍数希釈 し, EDTA添加好中球浮遊液 $0.05 \mathrm{ml}$ を加えて, パラフ ィルムで封じ， $37^{\circ} \mathrm{C}$ 水槽中に餒置し，5時間後ま たは18時間後に倒立顕微鏡で観察した。倍率 100 倍の視野で観察し，約100\%の細胞が凝集してい る時 $(4+)$, 約 $75 \%$ のさ $(3+)$, 約 $50 \%$ と き $(2+)$, 約 $25 \%$ とき $(1+)$, 顆粒球凝集の

表 3 . 血清，IgGおよびIgMの白血球凝集素価

\begin{tabular}{|c|c|c|c|c|c|c|c|}
\hline \multirow{3}{*}{ Dilution } & \multicolumn{3}{|c|}{ Leukocyte Agglutinin riter } & \multicolumn{4}{|c|}{ (Incubation Time: 5 hours ) } \\
\hline & \multirow{2}{*}{\begin{tabular}{|l|} 
Patient's \\
Serum \\
before \\
treatment
\end{tabular}} & \multirow{2}{*}{$\begin{array}{l}\text { Patlent's } \\
\text { Serum } \\
\text { serter } \\
\text { thertment }\end{array}$} & \multirow[t]{2}{*}{$\begin{array}{c}\text { Normal } \\
\text { Serum }\end{array}$} & \multirow{2}{*}{$\begin{array}{l}\operatorname{lgG} \\
\text { No. } 4 \\
(1.50 \mathrm{mg} / \mathrm{ml})\end{array}$} & $\begin{array}{r}196 \\
\text { No. } 7\end{array}$ & $\begin{array}{l}\operatorname{lgm} \\
\text { No. } 25\end{array}$ & $\begin{array}{l}\operatorname{lgM} M \\
\text { No. } 26\end{array}$ \\
\hline & & & & & \multicolumn{3}{|c|}{$0.27 \mathrm{mg} / \mathrm{ml} / 10.16 \mathrm{mg} / \mathrm{mbl} 10.21 \mathrm{mg} / \mathrm{ml}$} \\
\hline 1 & $\frac{1+}{1,+}$ & 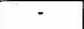 & - & $2+$ & $2+$ & - & - \\
\hline 2 & $1+$ & - & - & $2+$ & $2+$ & - & - \\
\hline 4 & $1+$ & - & - & $1+$ & $1+$ & - & - \\
\hline 8 & $1+$ & - & - & $1+$ & \pm & - & - \\
\hline 16 & $1+$ & - & - & \pm & - & - & - \\
\hline 32 & $1+$ & - & - & - & - & 5 & - \\
\hline 64 & $1+$ & - & - & - & - & - & - \\
\hline 128 & $2+$ & - & - & - & - & - & - \\
\hline 256 & $2+$ & - & - & - & - & - & - \\
\hline 512 & $3+$ & - & - & - & - & - & - \\
\hline 1024 & $3+$ & - & - & - & - & - & - \\
\hline 2048 & $2+$ & - & - & - & - & - & - \\
\hline$\overline{\text { Futer }}$ & $>2048$ & 0 & 0 & 16 & 8 & 0 & 0 \\
\hline
\end{tabular}




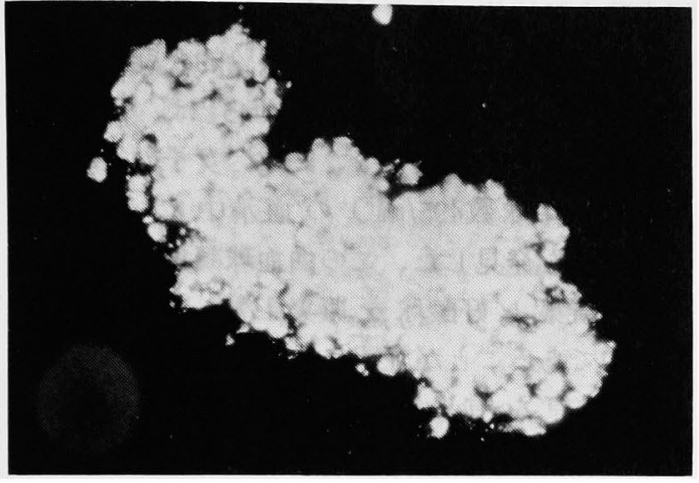

2 a

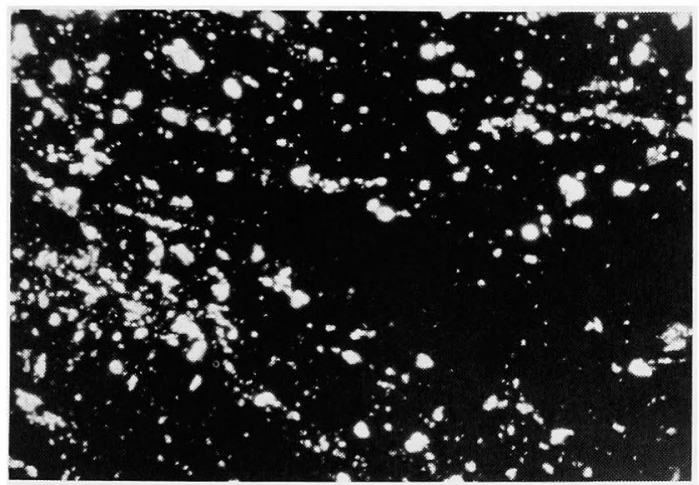

$2 \mathrm{~b}$

図2，a）白血球凝集反応陽性（患者血清）

b) 白血球凝集反応陰性（正常人血清） （写真は暗視野で $5 \times 20$ 倍撮影）

全く見られない時（一）と記載した．結果は表 3 に示す如く，ステロイド使用中止の 3 月には 2048 倍以上の白血球凝集素価を示したが，ステロイド 治療により好中球が増加した10月 3 日には血清白 血球凝集素は陰性化した。毎度, 正常対照群とし て正常人血清とその自己成熟好中球との間で白血 球凝集素を検索したが，常に陰性であつた．図 2 に白血球凝集素陽性像を示した．次いで本症例の

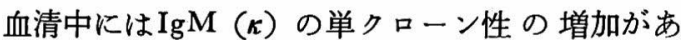
ク, 白血球凝集素が単クローン性 $\operatorname{IgM}(\kappa)$ に存 在するか否かを検索する目的で，IgGとIgMとを 分離した. 患者血清 $3 \mathrm{ml}$ を薄層等電点分画法 (flat bed electrofocusing $)^{5)}$ によつて，等電点 $5 \sim 8$ で 30分画に分離すると, IgGは主として, No. 1〜

\section{FLAT BED ELECTROFOCUSING}

(Patient's Serum : $3.0 \mathrm{ml}$ )

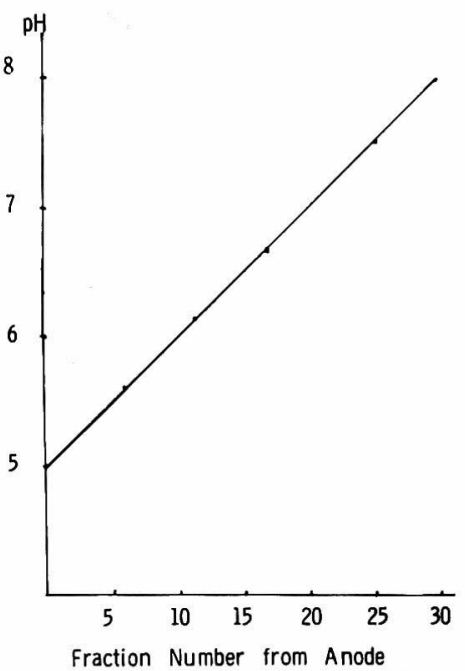

Anti-Gamma Chain

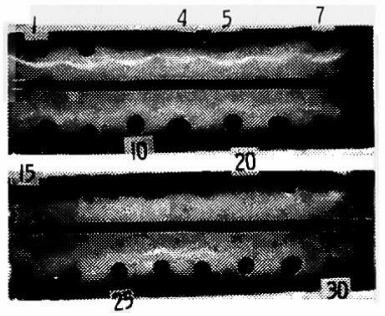

Anti-Mu Chain
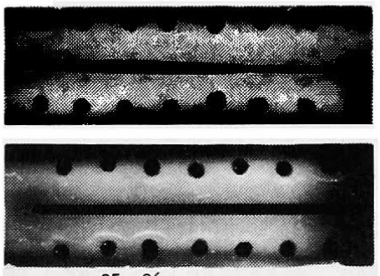

$25 \quad 26$

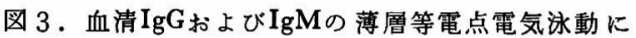
よる分離

9分画に，IgMは主としてNo. 25, No. 26の両分 画にそれぞれ分画された。 No. 26はIgM-IgGの 複合体を形成していると考穴られ，RA陽性所見 に合致した（図 3 ）。この中，No.4とNo. 7をIg G分画として, No. 25とNo. 26をIgM分画（単ク ローン性）として白血球凝集素を検索した。結果 は表 3 に示寸如く, IgG分画は白血球凝集素を有 し, 一方, 単クローン性IgMには白血球凝集素の 


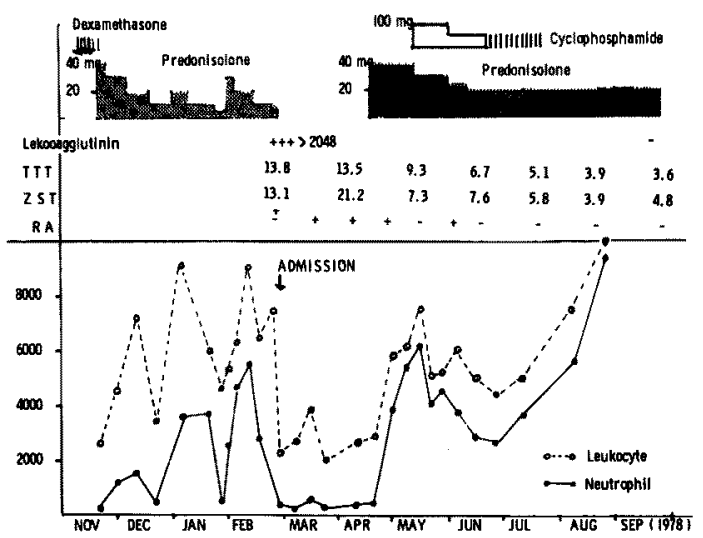

因 4.臨休程過

存在しないことが明らかにされた。

臨床释過； 2 月 27 日入院後プレドニソロンを 中止して検索をす寸め，4月19日からプレドニン $40 \mathrm{mg} /$ 日を開始したところ，1 週間後には好中球 数396/ $\mathrm{mm}^{3}$ から $2840 / \mathrm{mm}^{3}$ と著增した。 5 月11日より cyclophosphamideを併用したところ，骨髄抑制の 副作用が現われたため,プレドニソロン $20 \mathrm{mg} /$ 日 の単独投与に変更し以後良好に経過している（図 4). 3 月には2048倍以上を示した血清白血球凝 集素は，9月には陰性化し，ステロイド中止中の 高 $\gamma$ グロブリン血症, TTTおよびZSTの高值, RA 陽性などの異常所見もすべてプレドニソロン使用 後に急速な正常化をみた。

\section{考案}

本例は成熟好中球の減少, 骨䯣細胞中CFU-C の増加，骨䯣芽球叔よび好中球系前骨髄球，骨䯣 球の正常または増加, 高 $\gamma$-グロブリン血症, IgM （反）の単クローン性免疫グロブリン血症を伴い， 副腎皮質ステロイド剤に極めて良く反応した， IgG型白血球凝集素を有する自己免疫性好中球減 少症 (autoimmune neutropenia) である.

赤血球又は血小板に対する自己抗体によつて， 自己免疫性溶血性貧血又は一部の特発性血小板減 少性紫斑病が 蒸起されることは周知の事実であ る. 従つて自己抗体による好中球減少症の存在に ついても従来諸家により推定され，1952年以来，
好中球自己抗体の検索が行なわれてきたが ${ }^{67)}$ ，白 血球凝集素の検查法自体に方法論的な疑義が提起 されてきた。1975年にLalezariら”は，白血球凝 集素の改良検査を用いて，2才，女子の好中球減 少症 (好中球数 $495 / \mathrm{mm}^{3}$ ) 9 血清中に $\mathrm{IgG}$ 型白血 球凝集素を発見した。この白血球凝集素は好中球 のみを凝集し好酸球を凝集しないこと，NA2k 特異的であることが証明され，患者自体の好中球 がNA2抗原を有していることが判明したため， 自己免疫性好中球減少症の診断が確立された。本 報告例の好中球抗体は, Lalezariの方法と同様の 方法で実証したものであり，自己の好中球に対す るIgG型leucoagglutininであるが，好中球特巽抗 原 (neutrophil-specific antigens) に関してはなお 末検索である.

Lalezariのleucocyte-agglutination法は赤血球の 抗グロブリン試験と異なり，好中球抗体によつて 遊走能が活発化し，好中球が動員され㠜集を形成 する ${ }^{8)}$. 従つて, 好中球の運動を阻害する高温ま たは低温を避けること，細胞の死隇や分解を防止 するEDTAの添加などが，必要条件である. leucocyte-agglutination法以外に好中球抗体を検出する 方法として, 蛍光抗体法 ${ }^{9)}$ や抗グロブリン試験 ${ }^{10)}$ などす発表されているが，信頼性にかける欠点が 指摘される. 最近, Boxer ${ }^{3}$ らは, 好中球抗体が 好中球膜に結合後の好中球機能を判定する鋭敏な 方法を開発し注目される。すなわち，オプソニン 化した好中球が他のマクロファージに貪食される 所見や，好中球のlipopolysaccharideで被覆したパ ラフィン油滴領食能に対する抑制効果を示標とす る方法である。

1975年Lalezariの 症例報告以来, 自己免疫性好 中球減少症の症例は現在まで文献的に10例を数え るに過ぎない(11)-14). 年令は生後 5 力月から72才 に及び，10例中 9 例が女性例である点が注目され る。われわれの報告例は男性で，しかす IgM ( 型の単クローン性免疫グロブリン異常症を伴つて いる点でュニークな症例と考える。本例は, SLE, Felty症候群, 関節リウマチ, 脾機能立進症など 
表 4. 自己兔疫性好中球減少症の報告例の要約

\begin{tabular}{|c|c|c|c|c|c|c|c|}
\hline & Autol & nmune Neutra & penla & & & & \\
\hline |Author | & (Patient) & $(W B C)$ & 1 & inogy $\mid 00$ & (n) & I Response to & I Leukocyte \\
\hline $\begin{array}{l}\text { 1. Lalezary, } P \text {, ef al } \\
1975\end{array}$ & 2 years, 1 & $\begin{array}{l}9900 \\
\text { Neutro. } 10 *\end{array}$ & $\begin{array}{l}\text { lg̣g. } \\
1340 .\end{array}$ & $\begin{array}{l}19 A . \\
42 .\end{array}$ & $\begin{array}{l}\lg M \\
250(\mathrm{mg} / 6 \mathrm{l})\end{array}$ & $\begin{array}{l}\text { Ster } \\
\text { good }\end{array}$ & $\begin{array}{l}\text { Antibedy) } \\
\text { Leukoagglutinin. } \\
\text { NA } 2\end{array}$ \\
\hline 2. Neo, A, G. et al & 8 month, 1 & $\begin{array}{l}6600 \\
\text { Neutro. } 12 \%\end{array}$ & 780 & 94. & 120 & good & $\begin{array}{l}\text { Opsonizing, } \\
\text { Anti-Phagocytic }\end{array}$ \\
\hline $\begin{array}{l}\text { 3. Boxer, } L \text {, et al } \\
1975\end{array}$ & 20 years. 17 & $\begin{array}{l}\text { Neutro. } \\
70-672\end{array}$ & & & & good & $\begin{array}{l}\text { Opsonizing. } \\
\text { Anti-Phagocytic }\end{array}$ \\
\hline $\begin{array}{l}\text { 4. Boxer, Let al } \\
1975\end{array}$ & 72 years. 1 & $\begin{array}{l}1000 \\
\text { Neutro. 2\% }\end{array}$ & & & & splenectomy * & Cpsonizing \\
\hline 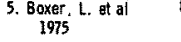 & 8 month, & $\begin{array}{l}\text { Neutro. } \\
285\end{array}$ & & & & good & $\begin{array}{l}\text { Opsonizlng, } \\
\text { Antl-Phagcytic }\end{array}$ \\
\hline 6. Boxer, $\mathrm{L}$. et al & 45 years, 1 & $\begin{array}{l}900 \\
\text { Neutro. } 12 \%\end{array}$ & & & & splenectomy * & Opsonizing \\
\hline $\begin{array}{l}\text { 7. Boxer, L. et al } \\
1975\end{array}$ & 50 years. 1 & $\begin{array}{l}\text { Granulocyte } \\
1600\end{array}$ & & & & good & $\begin{array}{l}\text { Opsonizing, } \\
\text { Ant1-Phayocytic }\end{array}$ \\
\hline $\begin{array}{l}\text { 8. Kay, A, 8. ot at } \\
1976\end{array}$ & 5 month. 1 & $\begin{array}{l}6900 \\
\text { Neutro. 3\% }\end{array}$ & 1200 & 110. & 154 & good & $\begin{array}{l}\text { Leukoagglutinin. } \\
\text { IgG \& igh }\end{array}$ \\
\hline $\begin{array}{l}\text { 9. Lightsey, A.L. et al } \\
1977\end{array}$ & 45 years, f & $\begin{array}{l}7200 \\
\text { Neutro. } 2 \%\end{array}$ & & & & & $\begin{array}{l}\text { Neutrophil- } \\
\text { blnding lgG }\end{array}$ \\
\hline $\begin{array}{l}\text { Thompson, A.L. et al } \\
1978\end{array}$ & & $\begin{array}{l}9300 \\
\text { Neutro. } 1 \%\end{array}$ & 1130. & 180 & 112 & good & $\begin{array}{l}\text { Leukoagglutirin. } \\
\text { Cytotoxic }\end{array}$ \\
\hline $\begin{array}{l}\text { Kozuru. M. et al } \\
1978\end{array}$ & 35 years. & $\begin{array}{l}2200 \\
\text { Neutro. } 14 \%\end{array}$ & 1180. & 353. & 516 & good & $\begin{array}{l}\text { Leukoagglutinin, } \\
\text { lgG }\end{array}$ \\
\hline
\end{tabular}

の基礎疾患を欠き ${ }^{15)}$, 明らかな化学薬品, 放射線 照射，感染症などの既往歴もなく、いわゆる特発 性自己免疫性好中球減少症と考えられる。しか し, 高 $\gamma$ ーグロブリン血症, $\operatorname{IgM}(\kappa)$ 型単クロー ン性免疫 タロブリン血症, RA弱陽性などの広範 な免疫グロブリン異常症を伴つて扣り，今後の注 意深い経過観察が必要である.

自己免疫性好中球減少症の治療には主に副腎皮 質ホルモン剂が適用され，文献上の従来報告では 症例10例中 7 例は文献的に副腎皮質ステロイド剑 が有効と判定されている. 本例も副腎皮質ステロ イド斉に極めて良好な反応を示し，ステロイド剤 の中止により好中球減少症の再発傾向を認めた

(表 4).

兔疫性好中球减少症 (immune neutropoenia) には自己免疫性好中球減少症 (autoimmune neutropenia）の他，新生児の同種免疫性好中球減少 症 (isoimmune neonatal neutropenia, INN) 方知 られている。INNの場合には胎览の好中球が胎 盤経由で母体を感作し，この好中球抗体IgGが 胎盤を通過して胎児に作用して 新生児の好中球 減少症を若起する。このINN 19症例の詳細な検 索から，亏ち18例に好中球特異抗原の存在が明 らかにされ，現在NA1 18例，NA2 1 例，NB1 7
例， $\mathrm{Vaz} 2$ 例など 4 種類の好中球特異抗原が同 定されるに至つている8).一方, 自己免疫性好中 球減少症では10例中わずか 1 例において好中球特 異抗原が分析され ${ }^{2)}$ ，NA2特異性であることが指 摘されて拈り，今後この方面の検索も必要亡考え る.

\section{䊅語}

単クローン性兔疫 グロブリン血症IgM $(\boldsymbol{x})$ を 伴つた自己免疫性好中球減少症の 1 例（35才， 男）を報告し，特に白血球凝集素はIgGに存在す ることを明らかにした．本例は自己免疫性好中球 减少症の本邦第 1 番目の報告例 と思われるが， Lalezariの報告（1975年）以来の外国での症例10 例の踟床像も要約して示した，好中球抗体の検索 には幾多の方法が考案されているが，本報告に示 したLalezariの方法は比較的簡易で信頼のおける 方法であり，好中球抗体の検索の普及に伴つて自 己免疫性好中球減少症の診断例む次第僧加する ものと期待される。

\section{文献}

1) Lalezari $P$ and Bernard G: Improved leucocyte antibody detection with prolonged incubation. Vox Sang 9:664, 1964.

2) Lalezari $\mathbf{P}$ et al: Chronic autoimmune neutropenia due to anti-NA2 antibody. New 
Engl J Med 293: 744, 1975.

3) Boxer LA, et al: Autoimmune neutropenia. New Engl J Med 293: 748, 1975.

4) Robinson WA and Pike BL: Colony growth of human bone marrow cells in vitro, "Symposium on Hemopoietic cellular Differentiation" ed. by Stohlman F, 1970, Grune \& Stratton, New York, p249.

5) Radola BJ: Isoelectric focusing in layers of granulated gels 1, Thin layer isoelectric focusing of proteins. BBA 295: 412, 1973.

6) Butler JJ: Chronic idiopathic immunoneutropenia. Amer J Med 24: 145, 1952.

7) Dausset JN: Auto-antileukocyte ribosomal fraction in leukoneutropenia. Ann N Y Acad Sci 124: 550, 1965.

8) Lalezari P and Radel E: Neutrophil-specific antigens: Immunology and clinical significance. Seminars in Hemat 11: 281, 1974.

9) Verheugt FWA, et al: The detection of granulocyte alloantibodies with an indirect immunofluorescence test. Brit J Haemat 36: 533, 1977.

10) van Loghem, et al: The incidence and significance of complete and incomplete white cell antibodies with special reference to the use of the Coombs consumption test. Vox Sang 3: 203, 1958.

11) Nepo AG, et al: Autoimmune neutropenia in an infant. $\mathrm{J}$ of Pediatrics 87: 251, 1975.

12) Kay AB, et al: Leucocyte function in a case of chronic benign neutropenia of infaney associated with circulating leucoagglutinins. Brit J Haemat 32: 451, 1976.

13) Thompson DS, et al: Auto-immune neutropenia in an infant. Postgrd Med J 54: 278, 1978.

14) Lightsey $\mathrm{AL}$, et al: Immune neutropenia. Ann Intern Med 86: 60, 1977.

15) Cline $\mathrm{MJ}$ and Golde DW: Immune suppression of hematopoiesis. Amer J Med 64: 301, 1978. 